\title{
Freshmen engineering course in an Oil \& Gas University
}

\section{Dr. Jaby Mohammed, The Petroleum Institute}

Jaby Mohammed is a faculty at The Petroleum Institute, Abu Dhabi, UAE. He received his PhD in Industrial Engineering from University of Louisville (2006), masters in Industrial Engineering from University of Louisville (2003) and also a master's in business administration from Indira Gandhi National Open University (2001). His research interests include advanced manufacturing, design methodologies, six sigma, lean manufacturing, and engineering education. He previously taught at Indiana Purdue Fort Wayne, IN and at Morehead State University, KY. He is a member of IIE, SME, ASQ, ASEE, and Informs. 


\title{
Freshmen Engineering Course in an Oil \& Gas University
}

\begin{abstract}
Industry engagements in engineering programs are becoming more common compared to the past. The freshmen success seminar course at The Petroleum Institute introduces the students to the oil and gas industry and in general to Abu Dhabi National Oil Company and its group companies in particular. Getting oil out of the reserves is not an easy task; a lot of manufacturing industries plays a vital role in setting up the infrastructure to create a well. In this course students are exposed to different manufacturing companies that are involved in the oil and gas industry.
\end{abstract}

\section{Introduction}

There are many first year programs that target the engineering students, In Lehigh University (Gardiner, 2004), students are required to take a mandatory course called, Introduction to Engineering Practice where the course accomplishes the goals like overview of engineering disciplines, introduction to engineering concepts, and career opportunities available for them. The course also introduces them to different technological needs that they would need to be successful. At Purdue University, the department of Engineering Education has responsibility for the entire first- year engineering students. All engineering students are brought into the First-Year Engineering Program that is part of the Department of Engineering Education. They are required to complete a common first year core of classes matriculating to their respective engineering major (Jeremy, 2006). As the industries and societies that revolve around faces mind-boggling challenges especially if one works with Information technology, manufacturing, oil or gas. They need for engineers in this field are very acute. Federal stimulus spending in such areas as energy technology and infrastructure shows an increase in demand. But there is still competition from emerging economies. The situation that is described with the current program is no different from the US economy. (National Academy of Engineering, 2005)

The first year program showcases the potential to engage students in a real life application of Science, Technology, Engineering, and Mathematics (STEM) coalition models that they learn in the classroom, to introduce engineering to students and the various majors (Mechanical Engineering, Petroleum Engineering, Electrical Engineering, Chemical Engineering, and Petroleum Geosciences) that is offered at The Petroleum Institute.

This course provides an opportunity for the student to learn and adopt methods and practices to enhance her/his success both in the PI and in the work place after graduation. Emphasis will be placed on the development of skills, attitudes and practical knowledge that will enable the student to reach his/her short and long-term academic goals. Themes will include: Time Management, Learning Styles and Team work. Exposure to the five degree programs through a series of lectures and guest speakers will help students make a mature and informed decision on their choice of major. The industry engagement in terms 
of field trip, lectures / seminar series will serves as the medium for reinforce. Also in this paper authors would show how they are able to incorporate other necessary skills that are required while they work in the oil and gas industry. The students use classroom knowledge and hands on experience to get to solutions, which may be difficult to show in a classroom setting for a technical subject.

To help the transition to college and specifically into engineering, the university has incorporated lessons, field trips, and lecture series to encourage students to identify a major most aligned with their interests and skills which will improve retention and interests in the field. Understanding how students choose and identify with a major is important in developing and accessing these programs. Few studies have assessed the effect of these first-year programs on how students choose a major (Ohland and Sill, 2002; Montgomery, Follman, and Diefes-Dux, 2003) but there are not many studies that have been undertaken for the oil and gas disciplines.

The paper will also address how the freshmen year students would relate the different majors to the manufacturing sectors related to the oil and gas industry.

- Ability to design system, and process to meet the desired needs with realistic constraints such economic, environmental, social, health and safety, and sustainability

- Ability to work in multidisciplinary teams

- Knowledge of the current issues

- Understanding professional and ethical responsibility

The Engineering Success Seminar (first year experience) is a semester long, four credit courses that is offered at The Petroleum Institute where the students would learn methods to be more productive with the industry engagement and hand-on project activity.

\section{Background}

The mission of the Petroleum Institute is to impart world-class education in engineering and applied sciences in order to support and advance the petroleum and energy industries. The Institute strives to develop students as whole persons and as the future leaders in their respective fields of expertise in the UAE and globally. The mission of The Petroleum Institute is to provide high quality engineering and science professionals through a continued commitment to excellence in its undergraduate and graduate academic programs alongside fundamental and applied research serving the Oil, Gas and Energy sectors' need for talent, solutions and advanced technical innovations that contribute to the UAE society and economy..

\section{Curriculum at The Petroleum Institute}

The PI was created in 2001 with the goal of establishing itself as an international institution in tertiary engineering education and research in areas of significance to the oil and gas and the broader energy industries. Currently the PI offers Bachelor degrees in 
Chemical, Electrical, Mechanical and Petroleum Engineering, and Petroleum Geosciences. The students after they go through the high school are admitted based on there TOEFL score and the GPA in high school. Most of the students go through a foundation program before they are enrolled as a freshmen student in PI. The foundation program is designed to help students develop knowledge, study skills, technical, analytical, and communication skills which are necessary to meet the PI's entrance requirements and assist them in their future studies at the Petroleum Institute. The foundation program at the PI is called as the Advanced University Placement program.

\section{Course framework}

Once the student reaches the freshmen level there are core courses that have to complete irrespective of their majors. The core courses are offered through the Arts and Science Program and some elective courses required for the engineering programs are also offered through Arts and Science.

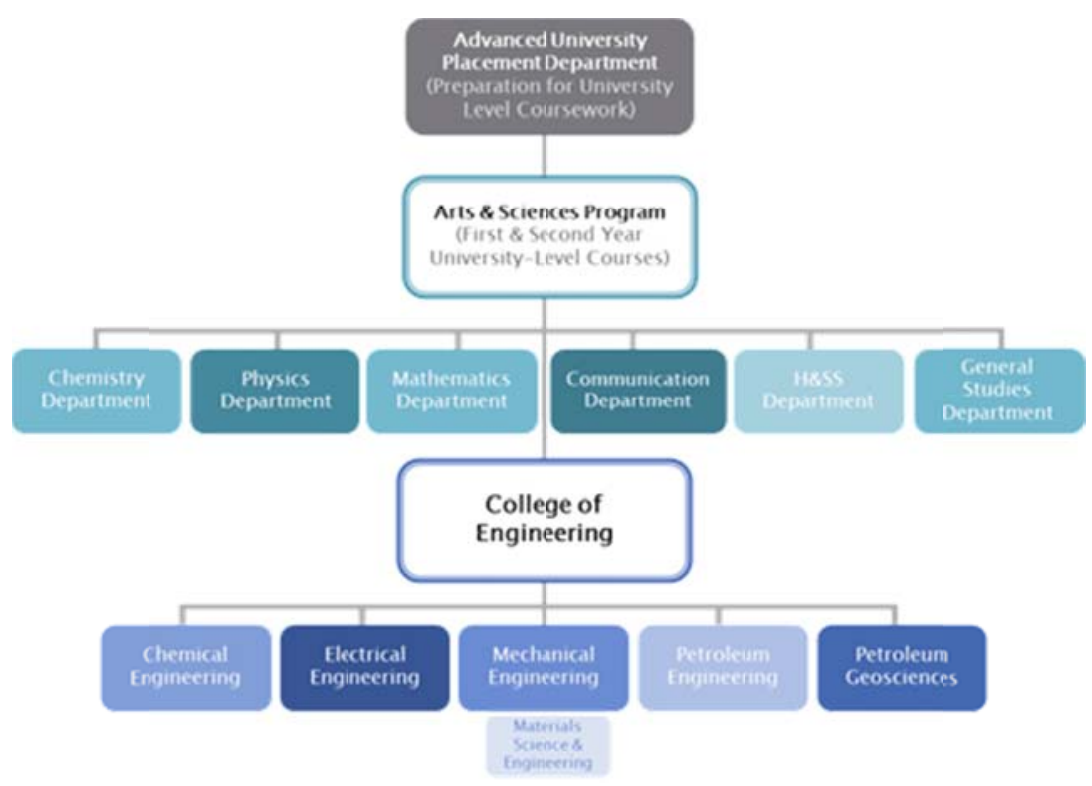

Figure 1. The Petroleum Institute Academic Department Structure

The six departments within the Arts and Science department include Mathematics, Physics, Chemistry, Humanities and Social Sciences, Communication, and General Studies (See Figure 1). Students must take these required courses in a sequence. One of the first courses that the students take is the freshmen success seminar.

\section{ENGR 101}

The freshmen engineering course, ENGR 101 is a four credit semester long course which comprises of two main topics, freshmen skills and topics that are related to petroleum industry. ENGR 101 This course enables students to gain an understanding of the petroleum industry, the role of engineers in this industry, the pathway to academic success in engineering studies, and membership into a learning community. Knowledge 
and skills gained will be applied by students to improve their performance in their engineering studies and in determining their choice of major. The development of the desired knowledge, skills and positive attitudes will occur through a series of studentcentered activities, field trips, and guest speakers from industry, including PI alumni. All of these activities are linked through the themes of exploring, producing, transporting, refining, processing, contributing and marketing. The course is at the center of establishing a structured learning community, a core aspect of the First Year Experience. "ENGR 101" combines two main topics. Their descriptions of the two main topics are given below.

- Skills for success in engineering school - under these topic students are provided with an opportunity for the student to learn and adopt methods and practices to enhance her/his success both in the PI and in the work place after graduation. Emphasis will be placed on the development of skills, attitudes and practical knowledge that will enable the student to reach his/her short and long-term academic goals. Themes will include: Time Management, Learning Styles and Team work, and ethics in the workplace. Exposure to the five degree programs, ADNOC and its operating companies, through a series of lectures and guest speakers, will help students make a mature and informed decision on their choice of major.

- Knowledge for the petroleum industry - under this topic comprehensive overview of the upstream and downstream sectors of the petroleum industry. Topics covered include formation and trapping of petroleum, geological and geophysical exploration methods, drilling, formation evaluation, reservoir engineering and production engineering. Refining, gas processing and the petrochemicals industries are also discussed. The economic and HSE aspects of the industry are considered throughout the course. An overview of the OPEC organization and supply-demands trends are discussed. The status of the oil industry in the UAE is emphasized and the roles of the various disciplines in the industry will be introduced.

\section{ENGR 101 course framework}

To be successful in engineering studies, it is important to plan and commit student's academic goals. Student must become a self-motivated learner and gain a repertoire of skills to adapt to academic demands and expectations (Landis, 2013). This transformation will occur when a student take control of their education. The purpose of this course is to facilitate development of appropriate behaviors and attitudes as they relate to the following areas: (1) orientation to PI; (2) community building; (3) professional development; (4) academic development; and (5) personal development. ENGR 101 is an integral course within the First Year Experience at the Petroleum Institute. Students are grouped together with other students into a living/learning community. A learning community is a group of people who are actively engaged in learning together. The key word here is actively. In this course student will learn both technical content (overview of the petroleum industry) and professional skills (skills that will enable them to succeed 
as a student and as a future ADNOC employee) through activities and experiences as shown in figure 2.

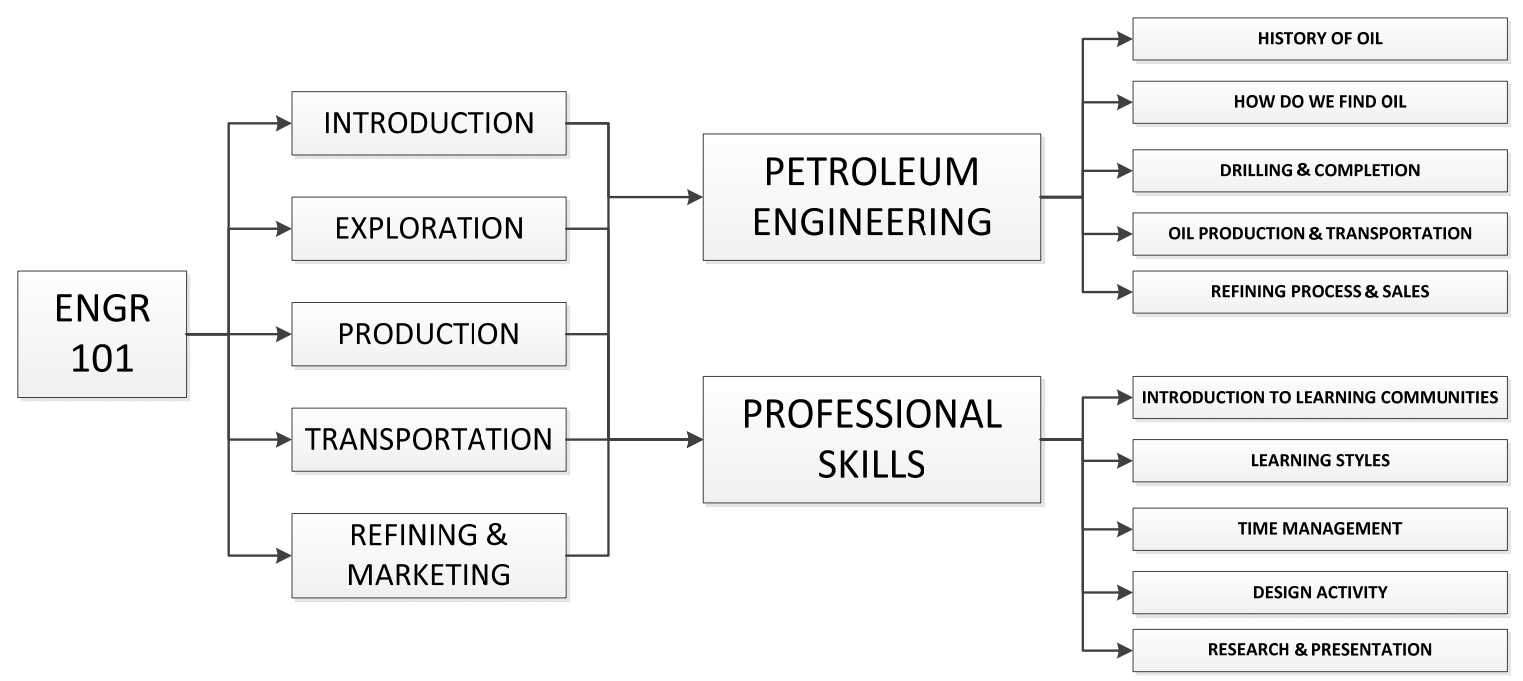

Figure 2: ENGR 101 framework

These will include mini-design projects, field trips, guest lectures, and opportunities to learn more about themselves as a learner and person. Enhancing student performance with respect to skills, as opposed to transferring information, requires alternative approaches to instruction. Research shows that students need to do more than take notes while listening in order to learn. The course is structured in such a way as to provide students opportunities to develop and practice skills and positive attitudes through interactive experiences. Students will spend substantial amounts of class time interacting with one another. Because of the student-centered nature of this course, students benefit from the other members of student learning community. In this class the instructor's role is that of a facilitator of the learning process. S/he will provide student with activities, and facilitate discussions. Activities and field trips have been chosen so as to engage students in individual and collaborative problem solving, analysis, synthesis, critical thinking, reasoning, and reflection. Students will learn through listening to others and sharing your ideas, and by doing. What students learn will depend directly on their willingness to participate and there preparedness for the class through reading the required materials before coming to class and doing the assigned tasks.

\section{Weightage for the various activities}

Formative and Summative assessments occur throughout the semester. The purpose of the assessments is to provide the learner with feedback regarding the level of development and understanding. Many of the assessment instruments also provide the students with an opportunity to reflect on their learning. Reflection is one of the most 
important aspects of the learning process in ENGR 101. The different assessments /assignments that will be used in this course and there percentage weightage are given below with a brief description on the assessment.

1. FYE Involvement activities passport (15\% weightage towards the final grade) -To extend the ideas explored in class, and enhance the First Year Experience, students are expected to participate in a variety of workshops and activities available to PI students. Students are expected to attend seminars, workshops, meeting with their advisor or, attend one tutorial or use the library for two hours each week, participate in PI extra-curricular activities, and contribute to a service. Student participation is documented in the FYE passport. These activities are ongoing throughout the semester. The passport is finally collected by the facilitator / Instructor at the end of the semester.

2. Writing Assignments (25\% of the overall score)-Writing in this course provides evidence of student's active participation, quality of understanding, and reflection. There are two essays. The first examines one of the 14 Engineering Grand Challenges for the $21^{\text {st }}$ Century. The second asks the students to connect their decision regarding their choice of major to the material that they have encountered in the course. Detailed task descriptions for each are provided to students. The third type of writing that they are asked to do is to reflect on the field trips. These reflections will ask students to think about what they have seen and learned, and connect it with the course activities and the goals of becoming an engineer.

3. Time Management Calendar and Reflections (15\% of the overall score) - In Week two of the course, students are requested to build a weekly schedule and a semester calendar. It is expected that students follow this schedule throughout the semester. As students adapt to university life, students may find those modifications are needed. Three times during the semester students are asked to reflect on how well they are following their schedule, and how well it is working. The reflections are written in to the student journal.

4. Petroleum Industry Overview Quizzes (10\% of the overall score) -During the semester there will be three short (15 minute) quizzes that will assess student understanding of the readings and lectures related to the overview of the petroleum industry. They will focus on petroleum industry vocabulary, processes and global issues.

5. Class activity points ( $10 \%$ of the overall grade)-- Throughout the semester there will be a series of activities completed in class individually, with a partner, or in a group. Each of these will be scored on a 2 (fully attempted), 1 (partially attempted), 0 (not attempted/absent) basis. Students must be in class to earn these points. No makeup assignments will be given. 
6. Current Events sharing ( $5 \%$ of the overall grade)-Each student is expected to present a 5minute mini-talk about a current world event related to the petroleum industry. The source for these- events should be newspapers or the Internet. At the start of each class session, two students will share their current event with the class, summarizing the article, stating why it is interesting, and highlighting its relevance to the UAE. The article along with a short paragraph

7. Journal (10 \% of the overall score) - The first year experience folder will be given to the students in week 2. It will include a notepad, which is to be used as student journal for this class. In the journal, students need to keep:

a. All notes taken in class

b. All field trip reflections

c. Time management calendar and reflections

d. Questions, issues, or perspectives you gained from the readings and would like to raise in class

e. Current event article link and paragraph

f. Reflections on what you gained from your FYE activities.

g. These journals will be collected twice during the semester for feedback. The final

h. Journal must be submitted to your instructor at the scheduled time of the final exam.

\section{Themes}

There are mainly five themes that are covered in the course; themes reflect both the petroleum industry as well as the professional skills. The various themes are listed below and these themes are covered in the 16 week semester

1. Introduction

2. Exploration

3. Production

4. Transportation

5. Refining

6. Marketing

Table 2 shows various professional skills and the petroleum skills that are covered in the various themes. Each theme component has an lesson / activity based on the professional skills as well as knowledge based on oil and gas industry. 


\begin{tabular}{|c|c|c|c|}
\hline Themes & Professional Skills & $\begin{array}{l}\text { Petroleum } \\
\text { Engineering skills } \\
\text { developed }\end{array}$ & Assessment medium \\
\hline Introductions & $\begin{array}{l}\text { Course Overview, Introductions, } \\
\text { Learning Communities, Journal } \\
\text { Keeping, Why PI? }\end{array}$ & $\begin{array}{l}\text { Building a learning } \\
\text { community, studying } \\
\text { engineering, A Brief } \\
\text { History of the Oil } \\
\text { Industry }\end{array}$ & $\begin{array}{ll}\text { - } & \text { Syllabus Quiz } \\
\text { - } & \text { Studying } \\
\text { Engineering } \\
\text { Reading }\end{array}$ \\
\hline Exploring & $\begin{array}{ll}\text { - } & \text { Time Management } \\
\text { - } & \text { Strategies for Success } \\
& \text { Assessing your Learning } \\
& \text { Styles, What is an engineer }\end{array}$ & $\begin{array}{l}\text { Petroleum } \\
\text { Origins and } \\
\text { Accumulation }\end{array}$ & $\begin{array}{l}\text { - Journal Assigned } \\
\text { (continues } \\
\text { throughout } \\
\text { semester) } \\
\text { - Weekly Schedule } \\
\text { and Semester } \\
\text { Calendar }\end{array}$ \\
\hline Producing & - $\quad$ Building a paper rig & $\begin{array}{l}\text { - Getting the oil } \\
\text { out of the ground: } \\
\text { Drilling and } \\
\text { Completion }\end{array}$ & $\begin{array}{ll}\text { - } & \text { Quiz } \\
\text { - } & \text { Filed trips }\end{array}$ \\
\hline Transporting & $\begin{array}{l}\text { - Engineering Design Activity - } \\
\text { Routing pipelines }\end{array}$ & $\begin{array}{l}\text { - Transportation of } \\
\text { oil }\end{array}$ & - Design activity \\
\hline $\begin{array}{l}\text { Refining \& } \\
\text { Processing }\end{array}$ & $\begin{array}{l}\text { Hone Your Skills: Making the } \\
\text { Grade, Getting the Most Out of } \\
\text { Your Assignments and } \\
\text { Preparing for Exams } \\
\text { - Visiting departmental labs and } \\
\text { hearing department } \\
\text { presentations }\end{array}$ & $\begin{array}{l}\text { - Separating and } \\
\text { Refining Crude } \\
\text { Oil }\end{array}$ & $\begin{array}{ll}- & \text { Field trips } \\
\text { - } & \text { Choosing Your } \\
& \text { Major” Essay }\end{array}$ \\
\hline Marketing & $\begin{array}{ll}\text { - } & \text { Engineering Design process } \\
\text { - Teamwork } \\
\text { - } & \text { Ethics }\end{array}$ & $\begin{array}{l}\text { - } \begin{array}{l}\text { Marketing } \\
\text { products }\end{array}\end{array}$ & - $\quad$ Field trips \\
\hline
\end{tabular}

Table 2: Professional and Technical skills covered in various themes

\section{Conclusion}

The Engineering Success Seminar (first year experience) is a semester long, four credit courses that is offered at The Petroleum Institute where the students would learn methods to be more productive with the industry engagement and hand-on project activity. The students get there first hand experience with engineering and gain knowledge in their professional and petroleum engineering technical skills by means of lectures, industry engagement to help them succeed in the oil and gas industry. 


\section{References}

Besterfield-Sacre, M., C.J. Atman, and L.J. Shuman, 1997. Characteristics of Freshman Engineering Students: Models for Determining Student Attrition in Engineering. Journal of Engineering Education, 86:139-149.

Gardiner, K. M., Oz Turk, S., “Developing a practical engineering experience for first year students”, Proceeding , ASEE Mid-Atlantic Spring conference, engineering student retention in the 21st century, April 23-24, 2004

Jeremy S., William C., and Imbrie P.(2006), “First year engineering student's choice of major: when it is made and what influences it"American Society for Engineering Education March 31-April 1, 2006 - Indiana University Purdue University Fort Wayne (IPFW),2006 Illinois-Indiana and North Central Joint Section Conference

Landis, R. B. (2013). Studying Engineering: A Road Map to a Rewarding Career, 4th Edition. Discovery Press, Los Angeles, ISBN 978-0-9793487.

Montgomery, R., Follman, D., Diefes-Dux, H. (2003) “The relative effectiveness of different first-year engineering seminars”, Frontiers in Education National Conference, Boulder, CO.

National Academy of Engineering (NAE), 2005. Educating the Engineer of 2020: Adapting Engineering Education to the New Century, Washington, DC: The National Academy Press.

Ohland, M. and Sill, B.(2002) "Communicating the impact of an introduction to engineering course to engineering departments.” Frontiers in Education National Conference, Boston, MA 